\title{
AN EXPLORATORY STUDY OF THE WAYS IN WHICH MOTHERS KEEP THEIR INFANTS OCCUPIED
}

\author{
Ailke Botha and Glenda Cleaver
}

\section{Opsomming}

Die moeder-kind verhouding is om verskeie redes belangrik vir 'n baba se sosiale, emosionele en intellektuele ontwikkeling. Navorsing dui daarop dat indien optimale interaksie tussen moeder en baba nie plaasvind nie kan dit die kind se kognitiewe ontwikkeling belemmer. Navorsing wat gedoen is met moeders uit lae sosio-ekonomiese groepe dui daarop dat moeders in hierdie groepe nie hulle babas optimaal stimuleer nie en dat dit moontlik 'n negatiewe effek kan hê op die kinders. In hierdie studie is onderhoude gevoer met 86 moeders uit lae sosio-ekonomiese groepe wat uit twee verskillende kultuurgroepe afkomstig is, om vas te stel hoe hulle hulle babas besig gehou het tydens die ecrste jaar. Die verskille tussen die twee groepe word bespreek en aanbevelings word gemaak.

\section{Absract}

The mother child relationship can helpor hinder the social, emotional and intellectual development of the infant. Research has shown that the interaction between mother and child can a ffect the child's cognitive development. Research has shown that mothers from the lower socio-economic groups do not stimulate their babies optimally and that this may affect the children negatively. In this study 86 underpriviledged mothers from two different cultural backgrounds were asked to describe the ways in which they kept their infants occupied during the first year of their infants' lives. The differences between the two groups are discussed and recommendations are made.

\section{INTRODUCTION}

There is some indication that certain types of experiences may facilitate infant development more than others. Emotional involvement and physical contact between mother and child are important for the formation of attachment and for a healthy emotional development in the child. Parent involvement is also important for the stimulation of cognitive skills in the infant. Several studies have found that cognitive development is strongly related to maternal involvement (Gottfried, 1984; Stevens \& Bakeman, 1985). There is evidence of a strong association between children's mental development and the quality of stimulation available to them in the first three years of life (Bradley \& Caldwell, 1982). Escalona (1968) found that frequent contact with the mother and a stimulating home environment were associated with accelerated development in infants.
Thus it would appear that the infant is in effect programmed to react to the stimulation of fered by the mother. The notion that stimulation is synonymous with bombarding the infant's senses is erroneous. Stimulation may be regarded as including everything the parents do with the child, such as touching, talking to, playing with and picking up the infant.

Cole, Gay and Sharp regard "cognitive development as primarily a social process whereby children acquire social skills as a result of interaction with others in culturally defined situations" (Jahoda \& lewis, 1988, p.12). By two months of age infants actually anticipate interaction with both mother and father according to the type of interaction that they have had previously with their parents. Trevarthan (1988) discusses research projects with infants from a few weeks of age to the middle of their second year. Ile notes that when confronted with unfamiliar toys infants look to their mothers in order to be shown what they should do and in what manner they should manipulate the toys. When they are presented with toys which are familiar to them they respond to the toys in familiar ways (the basis of which they presumably learned from family members in the past) and they appear to engage their mother in interaction with them if she is sensitive, flexible and supportive of their own independent efforts. If the mother does not respond to the infant's efforts in a co-operative manner the infant is inclined to ignore the mother. Stern (1985) discusses the interpersonal communion between mother and infant. He states that at about nine months of age a new dimension is added to the mother's imitation-like behaviour when interacting with the child. The mother's new category of behaviour is termed attunement. By this Siern means that the mother matches the infant's behaviour in intensity, rhythm and shape when interacting with the infant. This emotional exchange forms certain cognitive processes and is seen as the precursor to symbolic action and thought.

The strategies that mothers display when teaching or stimulating their infants seem to be the same across cultures and classes. However the extent to which mothers engage in teaching their infants appears to differ markedly. In a study in the United States of America with black mother-child pairs Hess, Shipman, Brophy and Baer (1969) found that mothers in the lower socio-economic groups were not inclined to explain activities to their infants or to provide a rationale for their instructions for the infants in contra-distinction to mothers from the middle class. Streissguth and Bee (1971) report that middle-class black mothers talk to their infants three times as much as do black mothers from a lower social strata. Middle-class infants also had more mobiles, toys, and rattles within view and within reach. The middle-class mothers orientated the child to the task with which he/she was occupied with more care, used more praise, and gave more specific feedback to the child. Among the underprivileged those who made use of the more "middle-class" strategy in teaching their children appeared to produce children who were more competent socially and intellectually than were the children of their counterparts. It 
should be kept in mind that the aforementioned investigations were not carried out in South Africa.

In South Africa Richter, Grieve and Austin (1988) found in an investigation of a group of 14 black mothers of infants aged 6 to 12 months that the mothers used the same methods to stimulate and teach their infants as had mothers in a similar study in Edinburgh. The mothers in their study regarded the task of teaching their infants as an innovation and they stated that they had not played with their infants in this way previously or consciously tried to teach them skills to help them manipulate toys. Richter \& Griesel (1986b) conducted an investigation involving 13.5 mothers. They found that mothers with adequately nourished children also tend to play more actively and more frequently with their children and to make more active attempts to teach their children skills or activities than do mothers with malnourished children

Richter and Griesel (1986a) found that black South African preschool children perform marginally below the American mean on a test of general psychological abilities $(\mathrm{N}=300)$. Caution should be exercised when drawing conclusions from studies in which group cohesiveness has not been specified and where the sample size is relatively small. A greater understanding of the interaction processes tween the infant and the parents is needed in order to bring about change in those children for whom a poor prognosis might be forecast. With this in mind an exploratory investigation was carried out in order to gain information on the ways in which South $A$ frican mothers kept their babies occupied during the first year of the babies' lives.

\section{METIIOD}

Two groups of mothers, one black (Tswana speaking), and one white (Afrikaans speaking), living in an urban area, were interviewed in respect of their methods of interacting with their infants in the first year of life of their eldest child. Fach group consisted of 43 subjects $(\mathrm{N}=86)$. The mothers were paired according to age and academic qualifications, ranged in age from 18 to 32 years and had an average of 9 to 12 years of schooling. The mothers had lower status white collar jobs such as clerks and cashiers. Income was not used as a variable, as many of the black families lived in multi-generational families, in which there are many incomes and often the mothers do not know what the income of the family is; in addition blacks usually earn less than their white counterparts. The average income of a black person with 10 to 12 years of schooling in the metropolitan area of Pretoria is R6378,20 per annum (Martins, 1986). This figure is not a reflection of the multiple income in the family. The annual income of the white families in this study was R36000 per year. The mothers were interviewed by trained field workers all of whom interviewed the respondents in their first language. The mothers were asked to describe how they kept their infants occupied during the whole of the first year of their infants' lives.

This is a retrospective study. At the time of the interview the child being discussed was between one and four years of age. This project formed part of a larger study and additional biographical information and other details are available in Cleaver and Botha (1990).

\section{RESULTS}

The protocols obtained were subjected to a content analysis (Miles \& Huberman, 1984). Two independent raters coded the protocols and the double-coding obtained was used to compute reliability. Pearson's product-moment coefficient revealed an inter-rater reliability of 0,96 (Statgraphics, 1986). The SAS-program was used in order to process the results. The chi square test was utilized to compute the biographical data. When expected frequencies are less than 5 , and when there is a $2 \times 2$ contingency table Fisher's exact test is more accurate than the chi square test (Siegel, 1956). Therefore Fisher's exact test was utilized on the remaining data. The results are listed in Tables 1 and 2 .

Approximately three quarters $(76,7 \%)$ of the white mothers were the primary caretaker for the infant while in the case of the black mothers approximately half $(46,5 \%)$ were the primary caretakers $(p<0,01)$. In the case of working mothers the black grandmothers played a much more prevalent role as caretakers than did the white grandmothers $(p<0,01)$. The white mothers who worked made proportionally more use of childminders. The family structures of the two groups differed markedly in that significantly more black mothers lived in

\section{TABLE1}

CHARACTERISTICS OF FAMILIES IN EACH OF THE TWO GROUPS

\begin{tabular}{|l|c|c|c|c|}
\hline \multicolumn{1}{|c|}{ MEASURE } & $\begin{array}{c}\text { FREQUENCIES } \\
\text { FOR BLACK } \\
\text { MOTHERS } \\
(\mathbf{N = 4 3 )}\end{array}$ & $\begin{array}{c}\text { FREQUENCIES } \\
\text { FOR WHITE } \\
\text { MOTHERS } \\
(\mathbf{N = 4 3 )}\end{array}$ & $\mathbf{X}^{2}$ & P \\
\hline PRIMARY CARETAKER & 20 & 33 & & \\
\hline mother & 18 & 5 & & \\
\hline grandmotherfamily & 5 & 5 & & \\
\hline childminder & & & 25,5 & $0,000^{\star \star *}$ \\
\hline FAMILY TYPE & 29 & 6 & & \\
\hline extended family & 13 & 34 & & \\
\hline nuclear family & 1 & 3 & & \\
\hline single parent & & & & \\
\hline
\end{tabular}

" $p<0,01$

** $P<0,001$ extended families than did white mothers ( $p<$ 0,001) (Table 1).

The results listed in Table 2 indicate that on the whole the mothers in the two groups used similar methods to keep their babies occupied. Most of the mothers gave their babies toys to keep them occupied ( $91 \%$ of the black mothers and $86 \%$ of the white mothers) or they used verbal communication in that they sang and talked to them (70\% of the black mothers and $84 \%$ of the white mothers). There was a significant difference between the two groups in respect of playing with the infants; $47 \%$ of the white mothers mentioned that they played with their babies, while only $5 \%$ of the black mothers made mention of the fact. The other areas in which there were significant differences between the two groups were taking the baby for walks, reading or telling stories to the baby and exposing the baby to music. There were no significant differences in the other methods the mothers used to keep their babies occupied.

The types of toys/objects given to the babies during the first year were by and large similar, except that the white mothers made more mention of soft toys and educational toys and the black mothers made more mention of dolls and cars.

In view of the fact that there was a significant difference between the two groups for the variables primary caretaker and family type an analysis was carried out in order to determine the role played by these variables. The results obtained indicate that in many cases these variables played a minimal role. The results given here involve only those variables where significant differences did in fact occur. Taking the blacks and whites together primary carctakers mentioned playing with their children significantly more often than did 
TABLE 2

ACTIVITY USED TO KEEP BABIES OCCUPIED

\begin{tabular}{|c|c|c|c|c|}
\hline ACTIVITY & $\begin{array}{c}\text { FREQUENCIES } \\
\text { FOR BLACK } \\
\text { MOTHERS } \\
(\mathrm{N}=43)\end{array}$ & $\begin{array}{c}\text { FREQUENCIES } \\
\text { FOR WHITE } \\
\text { MOTHERS } \\
(\mathbf{N}=43)\end{array}$ & $x^{2}$ & $\mathbf{P}$ \\
\hline Giving the baby toys & 39 & 37 & 0,45 & 0,50 \\
\hline $\begin{array}{l}\text { Verbal communication } \\
\text { (singing/talking to the baby) }\end{array}$ & 31 & 35 & 1,05 & 0,31 \\
\hline Playing with the baby & 3 & 19 & 15,64 & 0,00 \\
\hline Going for walks (with a pram) & 0 & 20 & 26,06 & $0,00 \mathrm{mon}$ \\
\hline Feoding the baby & 7 & 2 & 3,10 & 0,08 \\
\hline Using a baby walker & 7 & 2 & 3,10 & 0,08 \\
\hline Being with the baby all the time & 7 & 6 & 0,09 & 0,76 \\
\hline Putting the baby on her back & 5 & 1 & 2,87 & 0,09 \\
\hline Letting others entertain baby & 9 & 6 & 0,73 & 0,39 \\
\hline Putting the baby on the floor & 2 & 0 & 2,05 & 0,15 \\
\hline Sitting with the baby & 2 & 0 & 2,05 & 0,15 \\
\hline Showing the baby books & 2 & 0 & 2,05 & 0.15 \\
\hline Reading to the baby/story-telling & 1 & 7 & 4,96 & $0,03^{*}$ \\
\hline Playing with kitchenware & 1 & 5 & 2.87 & 0,09 \\
\hline $\begin{array}{l}\text { Exposing baby to music } \\
\text { (radio/hi-fi) }\end{array}$ & 0 & 6 & 6,45 & $0,01 *$ \\
\hline Swimming & 0 & 3 & 3,11 & 0,08 \\
\hline
\end{tabular}

* $p<0,05$

$p<0,01$

working mothers $\left(X^{2}=5,38 ; p<0,05\right)$. However, black mothers who were primary caretakers mentioned playing with their children markedly less than did white mothers who were primary caretakers $\left(X^{2}=12,01 ; p<\right.$ $0,001)$. As far as reading or telling stories to their infants was concerned the only significant difference that was found was that white mothers who were primary caretakers engaged in this activity far more than did white working mothers $\left(X^{2}=5,38 ; p<0,05\right)$.

Mothers from extended families and mothers from nuclear families differed significantly in respect of playing with their babies $\left(X^{2}=8,97\right.$; $p<0,01)$ in that those in the nuclear families mentioned playing with their infants more than did those from extended families. Black mothers from extended families differed significantly from black mothers from nuclear families in that those from the nuclear family played more often with their babies $\left(X^{2}=6,68\right.$; $p<0,05)$. Black mothers from extended families and white mothers from extended families differed significantly in that the white group mentioned that they played with their people are more likely to own books and therefore activities such as reading and showing pictures in books to children would be more possible for whites

Less than half of the mothers in both of the groups mentioned that they played with their infants in order to kecp them occupied. The babies in both groups were given objects with which to amuse themselves but very little actual play was engaged in. Although the white mothers engaged in this type of activity more than did the black mother, significantly more of the mothers in the white group were primary caretakers. Taking the two groups together the primary caretakers stimulate their offspring in this way more than the working mothers. Working mothers appear to play less with their children than do the non-working mothers, but it must be noted that the black primary caretakers mentioned playing with their offspring markedly less than did the white primary caretakers. Infants are actively involved in the process of acquiring cognitive skills (Piaget, 1970). The mother has a powerful influence on the form and nature of the communication and interaction that will take place between her and her offspring. Various studies (Gottfried, 1984; Stern, 1985; Stevens \& Bakeman, 1985; Trevarthan, 1988) highlight the role played by the interaction between mother and child in the development of cognitive skills. Richter, Grieve and Austi(1987) noted in their investigation in which the studied 14 mother-infant pairs that the mothers stated that they had not previously engaged in instructive play with their infants. The findings in the present study were similar. Studies indicate that middle class mothers play actively and engage in instructive play with their children more often than do mothers from lower socio-economic groups (Hess, Shipman, Brophy \& Baer, 1969). Under-privileged children appear to fare less well at school than do the more privileged. Griesel and Richter (1986) found that black pre-school children perform slightly below the levels achieved by their American counterparts on tests of psychological ability. It is possible that this state of affairs could be influenced by, amongst other things, the lack of stimulating play during the first year. When interpreting these results it should be kept in mind that although black mothers did not take deliberate steps to influence the development of their infants in this manner as often as did the whites, significantly more black than white mothers lived in extended families and the possibility exists that other adults in the family may fulfil this role. negotiate, making it easier for whites to take their babies for walks in perambulators. It should be kept in mind that a perambulator is a western invention used for taking children for a walk and that black mothers tend not to use perambulators. Nithough there is no significant difference between 'swimming' as an activity as far as the two groups is concerned 'swimming' is not a culturally accepted practice for black people. Therefore somc of the differences could be explained by cultural norms. More affluent
A few mothers in both groups mentioned feeding their infants as a way in which they kept them occupied, but mostly considered feeding as part of the normal daily routine.

A great deal of stress occurs when a mother is struggling to provide for her family's health (Cleaver \& Botha, 1989). Underprivileged 
women would, in accordance with Maslow's hierarchy of needs, focus on providing their babies with basic needs such as food and shelter rather than on other factors. Ajthough this is an exploratory investigation and the results should be treated with caution it would appear that the children in both the groups could benefit from more active participation in play on the part of their mothers. Mothers therefore should be informed of the importance of playing with their infants and they should be taught appropriate skills for this purpose. Cotterell (1986) found that functional support in child rearing (defined as the giving of information and advice) enhanced parenting skills for Australian working-class mothers. Nurses, psychologists, educationalists and other health professionals in contact with mothers both before and after the birth of their babies could, through instruction of mothers, facilitate the intellectual and emotional development of infants. It should be kept in mind that many grandmothers are the primary caretakers of their grandchildren as their daughters work and therefore they could also benefit from instruction and information.

\section{BIBLIOGRAPIIY}

BRADLEY, R.H. \& CALDWELL, B.M. 1982. The consistency of the home environment and its relation to child development. International Journal of Behavioural Development, 5, 44.5-46.5.

CleaVER, G. \& BOTHA, A. 1989. Experiences of motherhood amongst a group of Tswana mothers. Paper read at 7th Anthe South African Psychological Association. Durban. September.

COTTERELLL, J.L. 1986. Work and community influences on the quality of child rearing. Child Development, 57, 362-374.
ESCALONA, S.K. 1968. The roots of individuality: Normal patterns of development in infancy. Chicago: Adine.

GOTTFRIED, A.W. 1984. Home environment and early cognitive development: Integration, meta-analysis, and conclusions. In A.W. Gollfried (Ed.) Home Environment and early cognitive Development: Longitudinal Research. USA: Academic Press

GRIESEL, R.D. AND RICHTTER, L.M. 1986. The infuence of family background on the growi $h$ and development of black preschool children in South Africa. Paper presented at the $18 \mathrm{th}$ World Congress of the World Organisation for Early Childhood Education, Jerusalem, 13-17 July.

HESS, R.D., SHIPMAN, V.C., IBROPHY, J.E. AND BAER, R.M. 1969. The Cognirive enironments of urban preschool children: Follow-up phase. Chicago: University of Chicago Press.

JAHODA, G. AND LEWIS, I.M. 1988. Introduction: Child development in Psychology and Anthropology. In G. Jahoda \& I. M. Lewis (Fds.) Acquiring culture: Cross-cultural studies in child development. London: Croom II Iclm.

MILES, M.B. AND HUBERMAN, A.M. 1984. Qualitative data analysis. London: Sage.

PIAGET, J. 1970. Piaget's theory. In: P. Mussen (Ed.) Charmichaels: Manual of child psychology. New York: John Wiley.

RICHTER, L.M., GRIEVE, K.W. AND AUSTIN, D. 1988. Scaffolding by Bantu mothers during object play with their infants. Early Child Development and Care. 3, 3.

RICHTT:R, L.M AND GRIESEL, R.D. $1986 a$. Family life in urban black townships: Possible consequences for child development. Paper prepared for the fourth National Conference of the Psychological Association of South Africa, Johannesburg, 6-8 October.

RICHTER, L.M. AND GRIESEL, R.D. $1986 \mathrm{~b}$. Infant malnutrition in high density urban areas: some social and psychological factors. Paper presented at the $18 \mathrm{th}$ World Congress of the World Organisation for Farly Childhood Education. Jerusalem, July.

SIEGEL, S. 1956. Nonparamerric statistics for the behavioral Sciences. New York: McGraw-Hill.

STERN, D. N. 1985. The interpersonal world of the infant. New York: Basic Books.

STEVENS, J. H. AND BAKEMAN, R. 198. A factor analytic study of the Home Scale for infants. Developmental Psychology, 21, 1196-1203.

STREISSGUTH, A.P., AND BEE, H.L. 1971. Mother-child interactions and cognitive development in children. In: Hartup, W.W. (ed.). Reviews of Research. Vol. 2. Washington: National Association for the education of young children.

TREVARTHAN, C. 1988. Universal co-operative motives: How infants begin to know the language and culture of their parents. In G. Jahoda \& I. M. Lewis (Fds.) Acquiring culture: Cross-cultural Studies in child development. London: Croom Helm.

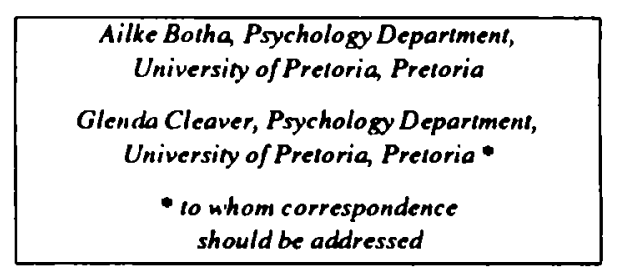

